\title{
Impact of Small Scale Irrigation on Smallholder Farmers' Livelihood Improvement: In Case of Damota Gale district, Wolaita zone, SNNPR
}

\author{
Abel Wudenah Abamagal \\ Department of Economics, College of Business and Economics, \\ Woliata Sodo University; Woliata Sodo, Ethiopia
}

Citation: Abel Wudenah Abamagal, 2019. "Impact of small scale irrigation on small holder farmer livelihood improvement in case of Damota Gale district, Wolaita zone, SNNPR, Ethiopia.

\section{Abstract}

This study mainly intended on impact of small scale irrigation on small holder farmer livelihood improvement in case of Damota Gale district, Wolaita zone, SNNPR. Mainly in this study both primary and secondary data were used which include qualitative and quantitative types of data. In study investigator employed multi-stage sampling technique based on this technique three kebele were selected and 140 respondent were selected from total household on study area. Structured questionnaire were used to collect essential primary data from sampled representative of irrigators and non-irrigators and employed both descriptive statistics and econometric model (i.e chi ${ }^{2}$, t-test, logit model and propensity score match) to analysis collected data. Both descriptive and propensity score match (ATT) impact analysis indicates that small scale irrigation have contribution on small holder farmers livelihoods. i.e. based on descriptive result small scale irrigation have significant contribution on income at $5 \%$ significance level and household monthly expenditure at $1 \%$ significance level from non-irrigators small holders farmers. Finally, average treatment on treat (ATT)impact analysis results revealed that small scale irrigation have statistically significant impact on small holder farmers agricultural output, income level and household expenditure. Small scale irrigation should be encouraged and developed by all small holders in order to improve agricultural production in return to improve livelihoods, So government and non-governmental organization should support small scale irrigation activities in order to reduce poverty or to improve living status especial those their aim is to reduce food insecurity.

Keywords: Impact, Small Scale Irrigation, Logit, ATT, Livelihoods, Damota Gale

DOI: $10.7176 / \mathrm{JESD} / 11-5-04$

Publication date:March $31^{\text {st }} 2020$

\section{CHAPTER ONE}

\section{INTRODUCTION}

Ethiopia economy predominantly dependent on agriculture activities like GDP, employment creation and its contribution for export is huge on average. Agriculture remains the main activity in the Ethiopian economy that contributor to the country's GDP: accounted, on the average, $65.5 \%, 52.7 \%$ and $47.1 \%$ of the GDP during 1960 1973, 1974-1991 and 1992-2002, respectively (Mulat et al, 2004). Recent data indicate that agricultural activities account for about $85 \%$ employment, $45 \%$ contribute for country's domestic product and $65 \%$ share from total export of countries (MoFA, 2007). Even there great contribution for country's economy in different ways the production agricultural remain as not exquisite since its dependence on rain feed agriculture and largest portion lands be determined on only rain. Ethiopia's GDP is generated through agriculture, and more than 12 million households rely on small-scale farming for their livelihoods and one of the drivers of growth in the agricultural sector has been the expansion of irrigation and also the country has seen the fastest growth in irrigation of any African country, area under irrigation increased by almost 52\% between 2002 and 2014 (Gebisa, 2019).

Irrigation is one of the agricultural technologies defined as the man made application of water to guarantee double cropping as well as steady supply of water in areas where rainfall is unreliable (Mutsvangwa et al, 2006). At the close of the last millennium, Ethiopia was irrigating fewer than 200,000 hectares (ha) of farmland, even though a total of 3.7 million hectares had been classified as potentially irrigable. This gross underdevelopment of capacity to grow food and industrial crops has spurred the Irrigation Development Program (IDP) to put an additional 273,829 hectares under irrigation and an increase of 135 per cent of currently irrigated farmlands, within its 15-year plan period of 2002-2016. For this reason, Ethiopia has the highest number of food insecure people and people who survive on less than a dollar a day (Tassew, 2004). That projected 52\% that from total population of country's is food insecure also $44 \%$ below the poverty line. Besides population growth of country there high growth and there is challenging environmental problem. According to Dagnew (2000), Ethiopia has deep-rooted poverty and food insecurity problems because country has high population growth, adverse climatic conditions, declining landholding size, degradation of the natural resource, limited access to institutional support services, and high dependence on rain-fed agriculture. Irrigation has long been in use in Ethiopia; nevertheless, it is far from 
satisfactory notwithstanding substantial investment, public basic interest and necessary strategic support through government policy. Henceforth, in Ethiopia until recently, only $2 \%$ of cultivated lands were irrigated (MoWR, 2001 ) and only $10 \%$ that means (3.5 million ha) of the estimated potential irrigable land is actually irrigated (Berhanu and Pedon, 2002). In Ethiopia irrigation schemes categorized into different typology; small scale irrigation those schemes cover less than 200 hectors which traditional scheme managed and developed by community tradition and usually characterized by non-fixed structures and practiced traditionally. Medium scale, schemes exceeding 200 hector but less than 3,000 hectors and large scale schemes exceeding 3,000 hectors two are mostly public schemes, owned and managed by the government, and in certain cases by large communities (Seleshi et al, 2007).

In many area of country having inadequate rainfall and country economic dependence on agriculture activities make small scale irrigation an important policy issue and human activity (Seleshi, 2007). Small scale irrigation is an important strategy in reducing risks associated with rain fall plays dominant role in increasing agricultural productivity. Ethiopia's agriculture is dominated by small-scale rain-fed production whose performance is subject to, among others, irregular rainfall pattern. Small-scale irrigation is believed in helping to address this problem thereby reducing rural poverty, food insecurity as well as improving the overall contribution of agriculture to the national economy (Tizita, 2017). Small scale irrigation also help poor farmers to overcome rainfall and water constraint by providing a sustainable agricultural, provide to increased food security to poor, communities and contribution to the improvement income in communities (Asfew, 2007). The development of small scale irrigation is one of the major intervention areas for government to boost agricultural production in the rural parts of the country (Desta, 2004) and Improved water management for agriculture has many potential benefits in efforts to reduce vulnerability and improve productivity (Awulachew et al, 2010).

Uneven distribution of rain fail south region makes small scale irrigation important on agricultural production to enhance food production. Currently government gives high attention and implementing different policy rise small scale irrigation activities particularly to reduce risk through irrigation and minimize farmer's dependency on rain-fed agricultural production (MoFED, 2010). Irrigation and good water management embracing of small holder farmers since it reduce agricultural risk caused rainfall variability, enhance productivity per unit of land and improve livelihood. According to Dereje et al (2006) state that irrigated agriculture has positive contribution on households' expenditure which implies that it improve livelihood's; similarly small scale irrigation role on small holders livelihood's (Balaran, A and Oladele,O.I, 2014), successful schemes increase income, productivity and job opportunity (Selish, 2007). In its contribution on agricultural production tradition irrigation have positive impacts on income and food security that farmers adopt traditional irrigation rise their crop productivity and possibility of multiple production (Musa, 2008 and Ogunniyi et al, 2018).

Likewise, according to Tizita (2017); Adugna et al (2013) and Lipton et al (2004) state that irrigated agriculture can reduce poverty through increased production and income, and reduction of food prices, which assistance small holder to meet basic needs in improving overall welfare and reduce risk of crop loss due to variability on rain fall and endorse use of yield enhancing farm inputs which in the long run enable them to move out of the poverty trap. Other scholar show success rise in irrigation because of irrigation and agriculture become governmental agenda (Gebisa, 2019). However, most of those study where out of Ethiopia and main focus of their objective is on medium irrigation, hence this study intended on impact of small scale irrigation on small holder farmers livelihood improvement in case of Damota Gale district, Wolaita zone, SNNPR

\section{CHAPTER TWO \\ RESEARCH METHODS}

\subsection{Description of the Study Area}

Damot Gale is one of 12 districts in Wolayta zone of SNNPR in Ethiopia. It is located at $139 \mathrm{~km}$ south west of the Hawassa town which is the capital of Southern Regional State and $365 \mathrm{~km}$ from Addis Ababa in the southern direction. Geographically, it is located between $6053^{\circ}-7^{0} 6^{\prime} 30^{\prime \prime}$ North latitude and $37^{0} 46^{\prime}-37^{0} 58^{\prime}$ 40" East longitudes. It has an altitude ranging from 1501- 2950 meters above mean sea level. Damot Gale district is divided in to three agro-ecologic zones such as Dega or high altitude (25.3\%), Woinadega or mid-altitude (61.2\%) and Kola or low altitude (13\%) DGWAO, (2014). Woinadega dominates the study area which has bimodal distribution of rainfall. Based on the CSA (2011) estimation and districts Finance and Economic Development office report, Damot Gale has a total population of 177,570 out of this male 103,011 and female 74,559. The total households of the district are 30,767 of which male households, 26,417 and female 4,350 and has a total of 31 rural kebels

\subsection{Data Types and Sources}

In this study primary data that collected from both smallholder farmers were quantitative and qualitative types in its characteristics. In case of data source researcher used both primary and secondary source of data. Primary data include the actual information received from individual smallholder farmers' practice on small scale irrigation and 
contribution of small scale irrigation for adopted group and about determinants of adoption of small scale irrigation for both treated and untreated group. Also researcher used secondary source include all types of published material on small scale irrigation scheme and governmental office report data.

\subsection{Sampling techniques}

For this study investigator employed multi-stage sampling technique. At first stage Damota Gale district was selected purposively among 12 rural districts of Wolaita zone due to the potential of irrigation from other kebele in district. In second stage from 31 rural kebeles of Damota Gale, three kebeles were selected by using simple random sampling technique. In third stage researcher stratified all small holder farmers from each selected kebeles in two those small scale irrigation adopted group (irrigators) and non-adopted group (non-irrigators).

Sample size for each kebeles and study unit was fixed based on the proportion on scale irrigators. At the end by using proportionate stratified random sampling 140 small holder farmers were selected from the two (irrigators and non-irrigators) stratums from each selected kebeles. The objective for stratification of the sample respondents into adopter and non-adopter were enable researcher to analysis the impact of small scale irrigation on small holder livelihood.

\subsection{Methods of Data Collection}

To find reliable and consistence data researcher have been collect primary data through household survey from individual smallholder farmers (which encompasses both adopted and non-adopted of small scale irrigation in study area). In addition to the smallholder farmers survey secondary data were collected based on its necessity from different governmental institution like Damota Gale district Agricultural office and water and irrigation office concerning small scale irrigation. Structured questionnaire were used for this research to collect essential primary data from sampled representative smallholder farmers and the questionnaire will be pre-tested and amended based on the feedback to be reviewed. Also various secondary data were used in this study like published material and different documents of different government office.

\subsection{Methods of Data Analysis}

In this impact analysis researcher employed both descriptive statistics and econometric model. Specifically, descriptive statistics used to describe weight of both adopter and non-adopter of small scale irrigation smallholder farmers demographic and socio-economic characteristic in study area. For this purpose descriptive statistics such as mean, standard deviation, percentage and t-test for continues variables and $\mathrm{chi}^{2}$ for dummy variables was employed. Since descriptive statistics are important tools to present research results clearly and concisely. In case of that to compare and contrast different categories of sample units with respect to the desired characteristics (covariates), so as to draw some important conclusions.

Mainly in this study econometric model were employed to analysis role of small scale irrigation on smallholder farmers, thus logit model and propensity score match employed where propensity score match employed to found quality match covariate among adopter and non-adopter for the purpose of difference compression. In most case there is methodological difficulty in the estimate effect obtained by comparing a controlled group with uncontrolled groups could be biased because self-selection and systematic judgment problem (Dehajia and Wahba, 2002).

The correct solution for this puzzle is propensity score matching, since it reduce dimension of covariate by matching covariates of controlled and uncontrolled groups. Becker and Ichino (2002) show that a specific direction to reduce the high dimensionality of observables characteristics difficulty in impact evaluation by deploying propensity score matching. Since PSM reduce dimension of covariate, can balance observables between controlled and uncontrolled and reduces bias (Dehejia and Wahbia, 2002). Likewise, Rubin (1983) proposed PSM as a method to reduce bias in the estimation of treatment effects with observational data set. Therefore, in this study propensity score matching have been employed in order to evaluate impacts of small scale irrigation on smallholders' livelihood in study area.

Empirically, the propensity score is the conditional probability in receipt of a treatment given pre-treatment characteristics, $\mathrm{X}$ (individual household head level of characteristics).

$$
\mathrm{P}(\mathrm{X})=\operatorname{Pr}\{\mathrm{D}=1 \mid \mathrm{X}\}=\mathrm{E}\{\mathrm{D} \mid \mathrm{X}\}
$$

Where $\mathrm{D}=\{0,1\}$ is the binary variable indicating whether a household are adopt small scale irrigation on agriculture (1) or not adopt $(0)$ and $\mathrm{X}$ is the multidimensional vector of treatment characteristics relatively stable household characteristics in own context.

Logistic regression was employed to predict the probability of each household adoption in the program as a function of observed household characteristics from both adopted and non-adopted group. In the logit model the adopted of the households was as dependent variable which takes the value of 1 for the household that already adopt small scale irrigation and 0 otherwise the same to as shown above.

The explanatory variables in this model are family size(Fsize), Age of household head(Ahh), Educational 
level of household head(EdHh), Maritial status of household(Mhh), Cultivated land size(CLsize), Credit access in area(Cracc), Household head off-farm activity(Hh-offa), Fertility of cultivated land(FCland), Labor force(Lforce), Extension service(Eservice), Distance from irrigation water source(DirrigWt), Total livestock amount(TLU) and income level of household head(IncHh).

The mathematical formulation of logit model is given by:-

$\mathrm{P}=\mathrm{E}(\mathrm{Y}=1 / \mathrm{Xi})=\frac{1}{1+e^{\beta 0+\beta i X i}}$

Then $\mathrm{p}_{\mathrm{i}=\frac{1}{1+e^{-z i}}} \quad$ for household participate in small scale irrigation activities

$1-\mathrm{Pi}=\frac{1}{1+e^{z i}}$ for household not participate in small scale irrigation activities

$\frac{P_{i}}{1-P_{i}}=\frac{1+e^{Z_{i}}}{1+e^{-Z_{i}}}$

$\frac{P_{i}}{1-P_{i}}$ the odds ratio in the favor of participating in the cooperative to the probability of household not participate. To normalize take natural log

$\mathrm{L}_{\mathrm{i}}=\ln \left(\frac{P_{i}}{1-P_{i}}\right)=\mathrm{Z}_{\mathrm{i}}=\beta_{0}+\beta_{1} \mathrm{X}_{1}+\beta_{2} \mathrm{X}_{2}+\beta_{3} \mathrm{X}_{3}+\beta_{4} \mathrm{X}_{4}+-----+\beta_{\mathrm{n}} \mathrm{X}_{\mathrm{n}}$

Where; $\mathrm{P}_{\mathrm{i}}=$ is a probability of being participated in the program; $Z_{i}=$ is a function of explanatory variables $\left(X_{\mathrm{i}}\right)$ which is also expressed as; $\beta_{0}=$ is an intercept and $\beta_{1}, \beta_{2}, \cdots \beta_{n}=$ are slopes of the equation in the model; $L_{i}=$ is $\log$ of odds ratio which is not only linear in $X_{i}$ but also linear in the parameters; $\left(X_{i}\right)=$ observable characteristics if the disturbance term and $u i$ is introduced to the logit model

$Z_{\mathrm{i}}=\beta_{\mathrm{o}}+\beta_{1} \mathrm{X}_{1}+\beta_{2} \mathrm{X}_{2}+\beta_{3} \mathrm{X}_{3}+\cdots+\beta_{\mathrm{n}} \mathrm{X}_{\mathrm{n}}+\mathrm{u}_{\mathrm{i}-}$

Here main question is how far household get improvement and reduce poverty favor in terms of poverty indicators as a result of participating in cooperative relative to household that not participating in cooperative for this researcher use average effect of treatment on treated (ATT). Therefore, impact of cooperative based on PSM is defined as follows by ATT:-

$\mathrm{ATT}=E\{Y i-Y o \mid D=1\}$

$\mathrm{ATT}=E(Y i-Y o \mid D=1)=E(Y i \mid D-1)-E(Y o \mid D=1)$

Where, $Y i$ the outcome in the household as treated group (improvement in livelihood of household this because household adopt small scale irrigation); $Y o=$ the outcome as controlled condition (improvement in livelihood for non-adopted household; and $\mathrm{D}=$ indicator variable denoting adoption of small scale irrigation (i.e. $\mathrm{D}=1$, household that adopt and $\mathrm{D}=0$, household does not adopt small scale irrigation). $E(Y i \mid D-1)$ is expected outcomes for those who treated; $E(Y o \mid D=1)$ is the counterfactual outcome that would have occurred in the absence of untreated. In order to estimate average treatment on treated (ATT) using the E[Y0/D $=0]$ mean outcome of untreated individuals leading to a self-selection bias because of the reason already stated above, the outcome of individuals from treated and untreated group would differ even in the absence of treatment (adoption of scale irrigation). It can be possible to note ATT as:

$\mathrm{E}[\mathrm{Y} 1 / \mathrm{D}=1]-\mathrm{E}[\mathrm{Y} 0 / \mathrm{D}=0]=\mathrm{ATT}+\mathrm{E}[\mathrm{Y} 0 / \mathrm{D}=1]-\mathrm{E}[\mathrm{Y} 0 / \mathrm{D}=0]$

Selection bias is defined as the difference between left hand side of equation (7) and ATT (6). Our main parameter of interest, ATT is only defined if:

$\mathrm{E}[\mathrm{Y} 0 / \mathrm{D}=1]-\mathrm{E}[\mathrm{Y} 0 / \mathrm{D}=0]=0$

Then ATT defined unbiased situation equation stated the same to above equation (6);

$\mathrm{ATT}=\mathrm{E}(\mathrm{Yi}-\mathrm{Yo} \mid \mathrm{D}=1)=\mathrm{E}(\mathrm{Yi} \mid \mathrm{D}-1)-\mathrm{E}(\mathrm{Yo} \mid \mathrm{D}=1)$

Under this two key conditions, Propensity score match (PSM) method applied to estimate ATT and to make it free from bias. The first is the conditional independence, in which assume that there exists a set of observable characteristics $(\mathrm{X})$, such that after controlling for these, the potential outcomes are independent of whether the individual is in the small scale irrigation adopted group or in the control group that they are not adopt small scale irrigation.

\subsubsection{Model Variable choice Dependent variable}

The p-score in this study generated by using different variables (characteristics) that expected to determine farmers' propensity to adopt small scale irrigation. The dependent variable of the study used in the logit analysis is a dichotomous/binary/ variable. The variable takes the value 1 if a smallholder farmers participate on small scale irrigation (considered as treatment group) and it takes the value 0 if a smallholder farmers did not used participative or did not adopt small scale irrigation (control group).

\section{Potential Outcome and Explanatory variables}

To evaluate the average treatment effects on treated, the study used a set of outcome variables those livelihood impacts of small scale on adopted smallholder farmers than non-adopted farmers. These provide transfers to the rural smallholder farmers economically empower and prevents asset depletion at the household level. In this study, the researcher considers three main impact indicators of small scale irrigation on smallholder farmers. Those main 
outcome variables in model were household income, expenditure, asset and agricultural output and explanatory variables for this model were family size, age of household head, educational level of household head, marital status of household, cultivated land size, credit access in area, household head off-farm activity, fertility of cultivated land, labor force, extension service, distance from irrigation water source, total livestock amount (TLU) and income level of household head.

\section{RESULTS AND DISCUSSION}

\subsection{Demographic and Socio-economic characteristics of respondents}

From total respondents based on horsehead sex $110(78.6 \%)$ male and remain percept $30(21.4 \%)$ also of respondents $22(16 \%)$ have off farm activities and $118(84 \%)$ have no off-farm activities on study area.

This part main focuses on inferential statistics both for categorical and continuous variables, i.e $\mathrm{x}^{2}$ for dummy variables and t-test for continuous variables. At this juncture from dummy variables four of them are significant different between adopt and adopted rural household in study area. Basically, households those have high opportunity to get access of credit have more probability to adopt small scale irrigation than other. The same to as presented in table 1, below descriptive statistics household access to credit significantly affect participation in small scale irrigation with significance level $1 \%\left(\mathrm{X}^{2}=15.45^{* * *}\right)$ and from adopted group 38(53\%) report as they have and $34(47 \%)$ oppositely inform there is lack credit for their agricultural activities. In other side from nonadopter of small scale irrigation households most of that $57(84 \%)$ of inform there is no credit access where only $11(16 \%)$ get credit access.

With respect to access of irrigation water in study area there is large significant difference between irrigation adopter and non-adopter household at 1\% (55.25) significance level. i.e from those participants household on small scale irrigation $60(83 \%)$ inform that there is sufficient water access for irrigation purpose and remaining $12(17 \%)$ not agree on having water access for small scale irrigation. From non-adopter case only $14(21 \%)$ inform that even if they are not start small scale irrigation lack of irrigation water access not their problem and conversely almost most of respondent from those not adopt small scale irrigation that mean $54(79 \%)$ report that there is water resource scarcity for irrigation. Other demographic and socio-economic variables that different among adopted and non-adopted group household is access of credit and development agent (DA) service concerning small scale irrigation, result show from total small scale irrigation user 34(47\%) and from non-user of small scale irrigation $11(16 \%)$ similarly agree on having credit access. Also $38(53 \%)$ from small irrigation adopter and $57(84 \%)$ have no credit access in study area. In case of development agent contact with small scale farmer or extension service from DA that check whether farmers get sufficient extension especially concerning small scale irrigation, among small scale irrigation adopted households $37(51 \%)$ and from non-adopted group $45(66 \%)$ reported that there is sufficient DA extension service. In other side, as revealed on table, 35(49\%) and 23(34\%) consent DA extension service on small scale irrigation from adopted and non-adopted farmers respectively.

Table 1: Descriptive statistics of household characteristics (for Dummy variables)

\begin{tabular}{|c|c|c|c|c|c|c|c|c|}
\hline \multirow{2}{*}{\multicolumn{2}{|c|}{ Explanatory variables }} & \multicolumn{2}{|c|}{$\begin{array}{l}\text { Adopted } \\
(\mathrm{N}=72)\end{array}$} & \multicolumn{2}{|c|}{$\begin{array}{l}\text { Non-Adopted } \\
(\mathrm{N}=68)\end{array}$} & \multicolumn{2}{|c|}{$\begin{array}{l}\text { Total } \\
(\mathrm{N}=140)\end{array}$} & \multirow[t]{2}{*}{$\mathrm{X}^{2}$} \\
\hline & & $\mathrm{N}$ & $\%$ & $\mathrm{~N}$ & $\%$ & $\mathrm{~N}$ & $\%$ & \\
\hline \multirow[t]{2}{*}{ Hhsex } & Male & 56 & 78 & 54 & 79 & 110 & 78.6 & \multirow[t]{2}{*}{0.055} \\
\hline & Female & 16 & 22 & 14 & 21 & 30 & 21.4 & \\
\hline \multirow[t]{2}{*}{ acctrain } & Av.train & 42 & 58 & 39 & 57 & 72 & 51 & \multirow[t]{2}{*}{0.014} \\
\hline & No.train & 30 & 42 & 29 & 43 & 68 & 49 & \\
\hline \multirow[t]{2}{*}{ acccredit } & have access & 38 & 53 & 11 & 16 & 45 & 32 & \multirow[t]{2}{*}{$15.45 * * *$} \\
\hline & No access & 34 & 47 & 57 & 84 & 95 & 68 & \\
\hline \multirow[t]{2}{*}{ Offactiv } & $\begin{array}{l}\text { Have off- } \\
\text { activity }\end{array}$ & 12 & 16 & 10 & 15 & 22 & 16 & \multirow[t]{2}{*}{0.445} \\
\hline & $\begin{array}{l}\text { No off- } \\
\text { activity }\end{array}$ & 60 & 84 & 58 & 85 & 118 & 84 & \\
\hline \multirow[t]{2}{*}{ irriwater } & Acc.water & 60 & 83 & 14 & 21 & 74 & 53 & \multirow[t]{2}{*}{$55.25 * * *$} \\
\hline & No acc & 12 & 17 & 54 & 79 & 66 & 47 & \\
\hline \multirow[t]{2}{*}{ acccredit } & have credit & 34 & 47 & 11 & 16 & 45 & 32 & \multirow[t]{2}{*}{$15.45 * * *$} \\
\hline & No credit & 38 & 53 & 57 & 84 & 95 & 68 & \\
\hline
\end{tabular}

Source: own survey data, 2019

\section{Household mean characteristic for continuous variables}

As shown below in table 2, mean difference for continuous household characteristics in case of both small scale irrigation adopted group and non-adopted groups. Mean family size for small scale irrigation adopted group household was 1.72 (family size on average between1-6) and for non-adopted group of household mean family 
size is 1.78 (family size between 1upto 7). The same to family size household head age insignificant in mean difference between adopted and non-adopted group with mean difference value -0.468.

Concerning age house hold head there no significant difference among those small scale irrigation use and with household that not used small scale irrigation. i.e 2.91 for adopted household group 2.83 for non-adopted households with standard deviation 0.667 and 1.25 respectively.

With respect to household head education level between two groups mean difference was 6.15 that statistically significant at $1 \%$ significance level. In detail small scale irrigation adopted group of household education level were more advanced than non-adopted group households as shown in table below. Next in case of number of ox/cow there is no significant difference between small scale irrigation user and non-user in study area, which means mean numbers of ox/cow were for adopted household approximately 3 and for non-adopted household 3 in average. Finally, as represented below cultivated land (land holding condition) was strongly significant difference between adopted and non-adopted group with in hectare at $1 \%$ Significance level. Figure in table indicate adopted group have mean 2.25 hectors on average and 2.52 for non-adopted households with mean of 2.385 .

Table 2. Descriptive statistics of house hold characteristics (for continuous variable)

\begin{tabular}{|c|c|c|c|c|c|}
\hline \multirow[t]{2}{*}{$\begin{array}{l}\text { Explanatory } \\
\text { variables }\end{array}$} & $\begin{array}{l}\text { Total } \\
(\mathrm{N}=140)\end{array}$ & $\begin{array}{l}\text { Adopted } \\
(\mathrm{N}=72)\end{array}$ & $\begin{array}{l}\text { Non-Adopted } \\
(\mathrm{N}=68)\end{array}$ & Diff in Mean & T-Value \\
\hline & Mean(STD) & Mean(STD) & Mean(STD) & Mean & \\
\hline Famsize & $\begin{array}{l}1.75 \\
(.720)\end{array}$ & $\begin{array}{l}1.72 \\
(.587)\end{array}$ & $\begin{array}{l}1.78 \\
(.843)\end{array}$ & -.057 & -.468 \\
\hline Agehh & $\begin{array}{l}2.88 \\
(1.007)\end{array}$ & $\begin{array}{l}2.91 \\
(.667)\end{array}$ & $\begin{array}{l}2.83 \\
(1.28)\end{array}$ & .078 & 0.459 \\
\hline Eduhh & $\begin{array}{l}2.45 \\
(1.18)\end{array}$ & $\begin{array}{l}2.98 \\
(1.21)\end{array}$ & $\begin{array}{l}1.89 \\
(.831)\end{array}$ & 1.089 & $6.15 * * *$ \\
\hline oxcow & $\begin{array}{l}3.86 \\
(.113)\end{array}$ & $\begin{array}{l}4 \\
(.168)\end{array}$ & $\begin{array}{l}3.72 \\
(.150)\end{array}$ & .278 & 1.23 \\
\hline cultland & $\begin{array}{l}2.385 \\
(.097)\end{array}$ & $\begin{array}{l}2.25 \\
(.118)\end{array}$ & $\begin{array}{l}2.52 \\
(.155)\end{array}$ & -.279 & $-1.44 *$ \\
\hline
\end{tabular}

Source: own survey data, 2019

4.2 Economic impact indicators for descriptive analysis

Table 3; Impact of small scale irrigation on household living status

\begin{tabular}{llllll}
\hline $\begin{array}{l}\text { Explanatory } \\
\text { variables }\end{array}$ & $\begin{array}{l}\text { Total } \\
(\mathrm{N}=140)\end{array}$ & $\begin{array}{l}\text { Adopted } \\
(\mathrm{N}=72)\end{array}$ & $\begin{array}{l}\text { Non-Adopted } \\
(\mathrm{N}=68)\end{array}$ & Diff in Mean & t-Value \\
\cline { 2 - 6 } prodairrig & Mean(STD) & Mean(STD) & Mean(STD) & Mean & \\
& $12026(1127)$ & $12872(1601)$ & $\begin{array}{l}11226 \\
(.069)\end{array}$ & $\begin{array}{l}1645 \\
(2259)\end{array}$ & .728 \\
incairrig & 3051 & 3292 & 2823 & $(469)$ & $1.49 *$ \\
& $(158)$ & $(239)$ & $(207)$ & $(315)$ & $6.15^{* * *}$ \\
expairrig & 2621 & 2827 & 2402.9 & 424.1 & \\
\hline
\end{tabular}

Source: own survey data, 2019

As shown in above table 3, small scale irrigation have contribution on individual household income, household expenditure and on productivity. However, all has not statistically significant contribution on household living status improvement indicators. Small scale irrigation have statistically significant role on household income status at $10 \%$ significance level by 1.49 t-values. i.e. monthly income for small scale irrigation user is 3292 birr and 2823 birr for non-user of small scale irrigation which implies mean difference is 469 monthly.

As per explained above, based on table results small scale irrigation have real and statistically significant contribution on household expenditure in study area. That means household those evolve on small scale irrigation have higher expenditure than from those non-user of small scale irrigation.

The difference were statistically significant at $1 \%$ and the difference were 424.1 birr which implies that household those encompass on small scale irrigation the consumption expenditure is greater than non-adopted group of house hold with 424.1 birr.

\subsection{Econometric Estimation Results}

\section{Propensity score matching model result}

Propensity score matching (PSM) was applied to deal with the main objectives (analysis the impact of small scale irrigation on livelihood) of study. Specific objectives of study are to evaluating impact of small scale irrigation on 
household production amount agricultural product, house hold income and household food expenditure study. As specified earlier in descriptive statistics result covariate for household both demographical and socio-economically condition varies significantly for most variables. Hence, the matching process was performed for all this specific object of study on livelihood indicators.

\section{Estimation Result of Propensity Scores}

As specified in the model specification part of study dependent variable a dummy variable indicating whether the household has been participate on small scale irrigation (take adopted) which takes a value of 1 and 0 , otherwise (non-adopted). The explanatory variables used are variables that explain involvement characteristics of the farmstead households and it engaged for matching adopted household with non-adopted group.

Logistic regression result as shown below in table 4 the pseudo- $\mathrm{R}^{2}$ value of estimated model result is 0.4699 which slightly less than 0.5 . Hence, results show small scale irrigation adopted households do not have diverse characteristics overall and obtaining a good match among adopted group and non-adopted household become easier.

Estimated coefficient results revealed that participation in small scale irrigation was significantly influenced by seven explanatory variables out of eleven variables that included as covariates. Households head education level determines the adoption status household at $10 \%$ significance level. i.e household with high education level more adopt small sale irrigation and conversely those with low education status adopt slowly than other. Similarly, family size influence household head adoption of small scale irrigation in study area at $10 \%$ significance level. Farming land size determine household head participation on small scale irrigation at 5\% significance level, that mean as result reveal household head with high cultivated land there is low probability to participate on activities.

Access of credit, access for training concerning agricultural production improvement and household trend to use improved agricultural input determine the adoption of small scale irrigation. As the shown in table 4 below, access for credit influence adoption of rural household at $1 \%$ significance level. Which means having sufficient credit access rise the adoption of individual house hold on small scale irrigation similarly, having access for training and household head using improved seed influence at $10 \%$ and $5 \%$ significance level respectively.

Finally, water access for irrigation has positive and statistically significant contribution for farmer adoption. That means irrigation water access influence farmers participation or adoption at $10 \%$ significance level. This implies that farmers with high irrigation water access have high probability to adopt irrigation rather than from those have no access.

Table 4. Logistic regression result for determinants of small scale irrigation.

- logistic adopted Sexhh Marthh Agehh Eduhh Famsize cultland acctrain useimpseed acccredit irriwater oxcow

Logistic regression

Number of obs $=140$

$\operatorname{LR} \operatorname{chi2}(11)=91.15$

Prob $>$ chi2 $=0.0000$

Log likelihood $=-51.410004 \quad$ Pseudo 2 2 $\quad 0.4699$

\begin{tabular}{r|rrrrrr}
\hline adopted & Odds Ratio & Std. Err. & $z$ & P ||$z \mid$ & [95\% Conf. Interval] \\
\hline Sexhh & .3719008 & .2959012 & -1.24 & 0.214 & .0781938 & 1.768813 \\
Marthh & .613594 & .3540179 & -0.85 & 0.397 & .1980495 & 1.901028 \\
Agehh & 1.126854 & .7463109 & 0.18 & 0.857 & .3076949 & 4.126816 \\
Eduhh & 1.855193 & .61121 & 1.88 & 0.061 & .972642 & 3.538548 \\
Famsize & .3231036 & .196178 & -1.86 & 0.063 & .0982924 & 1.062096 \\
cultland & .3995861 & .1818484 & -2.02 & 0.044 & .1637704 & .9749566 \\
acctrain & 7.079606 & 8.006132 & 1.73 & 0.084 & .771629 & 64.95455 \\
useimpseed & .0925353 & .1014892 & -2.17 & 0.030 & .0107831 & .7940964 \\
acccredit & .0519333 & .0519879 & -2.95 & 0.003 & .0073004 & .3694391 \\
irriwater & .2266132 & .1942609 & -1.73 & 0.083 & .0422284 & 1.21609 \\
oxcow & .9238713 & .2819019 & -0.26 & 0.795 & .5080229 & 1.680117 \\
cons & 384690.2 & 1503820 & 3.29 & 0.001 & 180.9751 & $8.18 \mathrm{e}+08$ \\
\hline
\end{tabular}

Source: own survey data, 2019

Matching among adopted and non-adopted group for small scale irrigation

Important three tasks carried out before conducting the matching work itself and impact of small scale irrigation. 
First, estimating the predicted values of adopted (propensity score) for all the sample households of both adopted and non-adopted groups (which were done in the previous section) are a primary activity.

Second, imposing a common support condition on the propensity score distributions of farmers with and without the small scale irrigation is another important task. This is to identify common area in both small scale irrigator and non-irrigator group that their propensity score fall in side interval. The final third task, dumping observations whose predicted covariate falls outside the range of the common support region is the next work. This is especially to robust of matching among adopted and non-adopted group on their identified covariates.

As per table 5 below, the estimated propensity scores for total observation vary between 0.0037 and 0.998 (0.461) for both adopted and non-adopted households. Estimated propensity scores for small scale irrigation user households that vary between 0.052 and 0.998 (mean= 0.764) and between 0.0037 and $0.961(\mathrm{mean}=0.329)$ for non-user of small scale irrigation households. Hence the common support region would lie between 0.052 and 0.961 which means households whose estimated propensity scores are less than 0.052 and larger than 0.961 are not considered for the matching purpose. As a result of this restriction only 9 households were discarded from observations. In short from all observation both members and non-members rural household total 9 observation was off common support.

Table 5: Distribution of estimated propensity scores

\begin{tabular}{llllll}
\hline Group & Observation & Mean & Std. Dev. & Min & Max \\
\hline Total Obs & 140 & 0.461 & 0.354 & 0.0037 & 0.998 \\
Adopted & 72 & 0.764 & 0.257 & 0.052 & 0.998 \\
Non-adopted & 68 & 0.329 & 0.245 & 0.0037 & 0.961 \\
\hline
\end{tabular}

Source: own survey data, 2019

\section{Choice of matching algorithm}

The decision on the final to choice fitting matching estimator was conducted based on three different criteria as proposed by Dehejia and Wahba (2002). First, equal mean test (referred to as the balancing test) that suggests a matching estimator which balances all explanatory variables (i.e., results in insignificant mean differences between the adopted and non-adopted groups) after matching is preferred. Second, basically pseudo- $\mathrm{R}^{2}$ value show in logit model significance of independent variable or covariate that its high value indicate high significance and small value also low significance. Therefore, competing by looking into pseudo- $\mathrm{R}^{2}$ value best, the smallest value is preferable because low value show small significance of covariates between adopted and non-adopted household. The third is a matching estimator /algorithm/ that ATT result with largest number of matched sample size is preferred. Implication is a matching estimator that balances all explanatory variables, with lowest pseudo- $\mathrm{R}^{2}$ value and produces a large matched sample size is preferable.

Based on stated criteria the best was from nearest neighbour matching is preferable by including high sample size the same to calliper and kernel algorithm. However, balancing test all have 11 and pseudo- $\mathrm{R}^{2}$ value best because fail in interval 0.052 and 0.140 . Therefore, nearest neighbour is best for this data than kernel and caliper estimators. In both result from nearest neighbour matching estimator neighbourhood 3 is first choose for this data because has small pseudo- $\mathrm{R}^{2}$ value $(0.052)$. Finally table result shows that nearest neighbourhood with neighbour 3 was found to be the best to assess impacts of small scale irrigation on household livelihood.

\subsection{Impact of small scale irrigation on livelihood}

Based on the study result impact analysis indicate that small scale irrigation beneficiaries earned an monthly income of 3289.5 Birr per household, which higher than that of non-users of small scale irrigation that 2821.2 monthly income. That mean small scale irrigation has statistically significant impact at 5\% significance level on household income status. This implies small scale irrigation has a positive impact on households earning from crop, and livestock, while the value of off farm income earning was higher for non-users. This finding is similar with findings of Getaneh (2011); Hussain (2004); Kinfe et al (2012) that show small scale irrigation have statistically significant impacts on household income that from agricultural activities.

Small scale irrigation create income generating opportunities by encourage surplus production since it create good opportunities in order to produce crop product more time in a year that means at difference season.

With reference to impacts of small scale irrigation on household's expenditure pattern was used as proxy in order to show living standard improvement. This improvement in household expenditure in turn indicates increment on their produce and high improvement on living status. Accordingly, the consumption expenditure for small scale irrigators is more than higher than of non-irrigators. That means the value of consumption expenditure is significantly higher than that of non-users small scale irrigation in study area. For instance as shown in table 6 below small scale irrigators expenditure 2803.3 birr and non-adopter is 2545 this is statistically significant at $5 \%$ and average treatment effect on treated was 258 birr (ATT). This indicates that access to small scale irrigation improves food security through consumption by increasing the frequency of production and it also enhances the capacity to access food through purchase. 
Table 6. Impact small scale irrigation household income level (ATT)

\begin{tabular}{lllll}
\hline Impact indictar Outcome & Adopted & Non-adopted & ATT & T-value \\
\hline Agricultural out put & 12982 & 11640 & 1312 & $1.53^{*}$ \\
Income level & 3289.5 & 2821.2 & 468.3 & $2.27^{* *}$ \\
Household expenditure & 2803.3 & 2545 & 258 & $5.04^{* *}$ \\
\hline
\end{tabular}

Source: own survey data, 2019. Note: $* * *$ denote significance at significance level $5 \%$ and at $10 \%$.

Similarly this section focuses the impacts of small scale irrigation on rural household gross yield of major crop production level between irrigator and non-irrigator. As data analysis indicate gross yields that both cereal and horticulture crops is higher for those household adopted small scale irrigation than non-adopted. An impact is statistically significant at $10 \%$ significance level and average treatment effect on treated was $1312 \mathrm{~kg}$ (ATT) this implies for irrigator $12982 \mathrm{~kg}$ and 11640 for non-irrigators. This evidence has ensured that small scale irrigation use is a guarantee for increased food supply and ensured food security. This is also an indication of the fact that irrigation use increases cropping diversification and intensity. This result is similar with Getaneh (2011) which implies irrigation use has significantly contributed towards achieving household's goal of increased production.

\section{CONCLUSION AND RECOMMENDATION}

The main issue that focus in this study were on impact of small scale irrigation on small holder farmer livelihood improvement in case of Damota Gale district, Wolaita zone, SNNPR. In this study we use both inferential statistics and econometric model like logit and propensity score matching (Pmatch).

Based on the result of inferential statistics small scale irrigator have higher income level that from those nonirrigator. i.e the mean difference for small scale irrigator was 315 birr monthly than non-irrigator and the difference was statistically different at $10 \%$. Last impact indicator in this study was expenditure level of individual rural households, so based expenditure level small scale irrigator have higher expenditure which implies higher consumption than non-irrigator the mean difference is 424 birr and it is statistically significant at $1 \%$ significance level.

In case of econometric analysis results participation of rural household on small scale irrigation was significantly determine by education level of household head, family size, on the amount of land size (cultivated land size), household head exposure for training, household experience of using improved agricultural input, credit access and last but not least having irrigation water access. Concerning propensity score matching especially average effects of treatment on treated (ATT) result show that small scale irrigation has significant impacts on rural household livelihood. Specifically, as result indicate agricultural production amount, income level of individual household and consumption amount of irrigator is significantly higher than non-irrigator of small scale irrigation.

So, based on the main findings we recommend concerning body as follows:-

Small scale irrigation should be encouraged and developed by all stockholders in order to improve agricultural production. This can be done through provision of training, input availability, adequate extension service through DA and credit availability. In study area household complain concerning water resource for small scale irrigation activities, so government and non-governmental organization should support rural households by accessing irrigation water like micro dam.

Small scale irrigation has contribution on household income and expenditure (consumption) which in turn implies impacts positive impact on livelihood improvement. So government and non-governmental organization by which their aim is to reduce food insecurity should support small scale irrigation activities in order to reduce poverty.

\section{Reference}

Adugna E, Ermias A, Mekonnen A and Mihret D, (2013). The role of small scale irrigation in poverty reduction, Vol. 6(1)

Bekele, M and Aster D, (2007). Impact of Irrigation on Poverty and Environment in Ethiopia; Draft Proceeding of the Symposium and Exhibition held at Ghion Hotel, Addis Ababa, Ethiopia 27th -29th.

Dagnew E (2000). The role and contribution of non-governmental organizations in food security in Ethiopia. Paper presented at the panel discussion on the 30th anniversary ofAgri-service Ethiopia, February.

Dehejia RH, Wahba S (2002) Propensity score-matching methods for non-experimental casual studies. Rev Econ Stat 84: 151-161.

Dereje B, Regassa N, Ayalneh B and Abonesh T, (2006). Impact of small-scale irrigation on household poverty: empirical Evidence from the ambo district in Ethiopia.

DGWAO. (2014). Annual Report on Emergency, Food Security and Early Warining. Damot Gale Woreda Agricultural Office.

Gebisa, F.(2019). Investment in irrigation is paying off for Ethiopia's fast-growing economy, Purdue University. 
Getaneh KA (2011). The impact of selected small-scale irrigation schemes on household income and the likelihood of poverty in the Lake Tana basin of Ethiopia. M.Sc. Thesis, Cornell University.

Hussain I (2004). Assessing Impacts of Irrigation on Poverty: Approaches, Methods; Case Studies and Lessons. International Water Management Institute (IWMI).

Kinfe A, Chilot Y, Rajan S (2012). Effect of small-scale irrigation on the income of rural farm households: the case of Laelay Maichew district, central Tigray, Ethiopia. J. Agric. Sci.7:1

MOFA (2007). Food security strategy for Ethiopia. Ministry of Foreign Affairs of (FDRE) Federal Democratic Republic Government of Ethiopia.

MoFED (Ministry of Finance and Economic Development), (2010). Growth and transformation plan (GTP) 2010/11-2014/15, Volume I, Main text. Addis Ababa, Ethiopia.

Ministry of Water Resources (MoWR). (2001). Irrigation Development Strategy (Component of the Water Sector Development Strategy). Draft Report. Addis Ababa, Ethiopia.

Mutsvangwa, T. Agriculture and Sustainable Development, Netherlands, The Hague University Press, 2006.

Ogunniyi A, Omonona B, Abioye O and Olagunju K. (208). Impact of irrigation technology use on crop yield, crop income and household food security in Nigeria: A treatment effect approach

Rubin DB (1973) Matching to remove bias in observational studies. Biometrics 29: 159-183.

Tassew W. (2004). The experiences of measuring and monitoring poverty in Ethiopia. A paper presented for the Inaugural Meeting of the Poverty Analysis and Data Initiative (PADI). Mombasa, Kenya. 